\title{
The Influence of Natural Monopolies on Cultural Democracy in the Performing Arts in Estonia
}

\author{
OTT KARULIN
}

\begin{abstract}
The core question of this article is to what extent has the state set securing cultural democracy (vs. the democratisation of culture as defined by François Matarasso and Charles Landry ${ }^{1}$ ) in the performing arts in Estonia as its policy goal. In Estonia, the theatre field is dominated by natural monopolies. These are companies that receive most of the financial subsidies in a respective field, making it economically non-viable for any other company to duplicate these resources. In Estonia, there are eight state-owned theatres (called G8-theatres) that collect, on average, $60 \%$ or more of the state subsidies for theatres, the state-subsidized theatre visits and the total income from ticket sales. As stated in the Competition Act of Estonia, company or companies that earn more than $40 \%$ of the turnover of the whole market are considered natural monopolies. Therefore, the G8-theatres are natural monopolies. The question whether the Estonian state has done enough to compensate non-governmental theatres (called NonGov theatres) for the aggregation of resources to natural monopolies is one of the main focuses of this article. Here, two strategies are analysed: the activity of the Cultural Endowment of Estonia and the state's attempt to invest in building an alternative infrastructure for NonGov theatres.
\end{abstract}

\section{KEYWORDS}

Cultural democracy, natural monopolies, Estonian theatre system, state subsidies for performing arts

$1 \quad$ Matarasso \& Landry 1999, 13-14.

ISSN 2002-3898

(C) Ott Karulin and Nordic Theatre Studies

PEER REVIEWED ARTICLE Open access: https://tidsskrift.dk/nts/index

Published with support from Nordic Board for Periodicals in the Humanities and Social

Sciences (NOP-HS) 


\section{The Influence of Natural Monopolies on Cultural Democracy in the Performing Arts in Estonia}

\section{INTRODUCTION}

This analysis will focus on three questions. Firstly, to what extent has the state set the securing of cultural democracy (vs. the democratisation of culture as defined by François Matarasso and Charles Landry ${ }^{1}$ ) in the performing arts in Estonia as its policy goal. For this, the state's culture-policy documents are analysed and a short overview of the changes in the Estonian theatre system since $1995^{2}$ is given.

Secondly, what role do natural monopolies play in securing cultural democracy in the performing arts in Estonia. Here, the functioning of theatres as natural monopolies will be described based on the Estonian theatre system, concentrating on the period after the economic crisis of 2008-2010. The definition of a natural monopoly is borrowed from the concept of the market economy: that is a company or companies that possess the majority of resources in a respective field, making it economically unreasonable for any other company to duplicate these resources. ${ }^{3}$ Therefore, the question of the influence of natural monopolies does not arise from artistic and/or ideological choices and is purely a matter of financing theatres and how this influences the (economic) functioning of these institutions. In other words: a theatre in Estonia is a natural monopoly when it is state-owned and has real estate

$1 \quad$ Matarasso and Landry 1999, 13-14

2 Estonia regained its independence in 1991, but it took some time to reorganise the new system and therefore the first reliable statistics regarding the activities of performing arts institutions come from the year 1995, which is also the starting point of statistical analyses in this article. The last year with verified and published statistics to date is 2015 , which is also the end-year for the analyses in this article.

3 Towse 2010. 
(venues) that the state is financing regardless of the artistic outcome while state subsidies for other theatres are usually decided upon by their artistic plans and even then, the resources available for them are limited.

And thirdly, what has the Estonian state done to compensate other theatres for the aggregation of resources to natural monopolies. Two strategies will be analysed: the activity of the Cultural Endowment of Estonia and the state's investments in building an alternative infrastructure for other theatres.

\section{FROM DEMOCRATISATION OF CULTURE TO CULTURAL DEMOCRACY} In his guidelines for UNESCO in 1972 Augustin Girard claimed that the first rule in any cultural policy "must be decentralisation", ${ }^{4}$ and that "any cultural policy adopted by a local community or an institution must reconcile various conflicting demands: freedom for artists and organizers, without which no culture exists; control by the elected representatives and administrators who are responsible for public funds; and participation of the users." 5

He concludes: "The decentralisation of activities, financing and the process of selection is at once both the first step in the direction of cultural democracy and essential to cultural creativity, vitality and freedom. Thus decentralization is necessarily the guiding principle of cultural democracy."6 Although Girard sees decentralisation as a means to achieve cultural democracy, he also argues that an "acceleration of cultural development is a necessity forced on rapidly changing societies", and that cultural development "has now ceased to be an article of luxury, an embellishment of plenty, which societies and individuals could do without; it is on the contrary linked to the very conditions of general development."7

So, following Girard, accessibility to culture for as many as possible should be the core purpose of the state's policy - and seems to have been, so that in 1999 François Matarasso and Charles Landry could conclude: "The post-war period has seen a steady increase in the engagement of European states with cultural issues, reflected in increasing public subsidy of cultural activity." the arts and a consequent desire to democratise access to it", ${ }^{9}$ (and what they call the democratisation of culture) was the main motivation for this increase - as Girard wished. However, Matarasso and Landry also refer to the criticism of such an approach of "giving people access to a pre-determined set of cultural values, expressions and products" that could be seen as "a "top-down" dispensation of elitist cultural values [...] which neglected or dis-

\footnotetext{
$4 \quad$ Girard 1983, 172.

$5 \quad$ Girard 1983, 176.

$6 \quad$ Girard 1983, 180.

$7 \quad$ Girard 1983, 16.

$8 \quad$ Matarasso and Landry 1999, 13.

$9 \quad$ Matarasso and Landry 1999.
} 
missed many forms of cultural expression and identity." ${ }^{10}$ Alternative to the democratisation of culture could be the principle of cultural democracy with the aim of "increasing access to the means of cultural production, distribution and analysis alongside those of consumption." 11

The dilemma of the democratisation of culture vs. cultural democracy was also analysed in a survey ordered by the Estonian Ministry of Culture in preparation for writing The general principles of the cultural policy up to 2020 (Culture 2020) in 2012. It concluded that in Estonia the fields of art that lean more to the democratisation of culture are those traditionally seen as fine arts, performing arts among them. The state policy documents governing these fields that were analysed for this survey were mostly occupied with securing access to experience artworks and relied on quantitative data (such as the number of theatre visits) in measuring the influence of the policy. ${ }^{12}$

Culture 2020, adopted by the parliament two years after the survey, states that the main objective of Estonian cultural policy is "to form a society that values creativity by maintaining and improving the national identity of Estonia, researching, storing, and transferring cultural memory, and creating favourable conditions for the development of a vital, open, and versatile cultural space and for participating in culture," thus still following the principles of the democratisation of culture, although it does also say: "The state creates opportunities for the development of culture and improving the accessibility of various cultural events for creators and participants alike. All Estonian residents must have a chance to create culture and to partake in it regardless of their regional, social, cultural, ethnic, age, gender-related or other individual characteristics and needs." 13

Another conclusion of the above-mentioned survey relevant to this article was the acknowledgement that the existence of the Cultural Endowment of Estonia that gives grants in addition to state subsidies, and where grants are decided by committees consisting of experts put forward by the institutions of the art field, does follow the principles of cultural democracy. ${ }^{14}$ The functioning of the said endowment as a compensation mechanism for non-governmental theatres operating in the market with natural monopolies is described later in this article but its basic operating principles, as described in Culture 2020, should be already quoted here: "The Cultural Endowment of Estonia mainly supports creative individuals and project-based initiatives, while the budget of the Ministry of Culture is used for funding the main activities of state-supported institutions and long-term activities that are important from

\footnotetext{
$10 \quad$ Matarasso and Landry 1999.

11 Matarasso and Landry 1999, 14.

12 Aadamsoo et al. 2012, 10-11.

13 The general principles of the cultural policy up to 2020 , adopted by the Estonian Parliament on 12.02.2014.
}

14 Aadamsoo et al. 2012, 10-11.. 
the aspect of national culture."15 In other words, the endowment is meant to balance the decisions of the Ministry in the context of cultural democracy as it "mainly supports creative individuals" whereas the Ministry focuses on institutions.

\section{NATURAL MONOPOLIES IN THE ESTONIAN THEATRE FIELD}

Regarding the institutions, there is no doubt that in the Estonian theatre system, which has its roots in the national awakening movement of the late 19th Century, the "decentralisation of activities, financing and the process of selection"16 as proposed by Girard have been well followed. Most state-owned theatres operating today were born as semi-professional peoples' activities in various parts of Estonia that provided a geographically well decentralised network of theatres (besides the capital there are state-owned theatres in five other cities). Today, the state owns ${ }^{17}$ the National Opera operating by its own law and eight other theatres operating as foundations. In addition, there are two city-theatres owned by the local government. In financing the performing arts institutions, the respective law states that the ownership of a theatre cannot be the basis on deciding the state subsidy and so the number of non-governmental theatres (abbreviated henceforth NonGov theatres) has risen exponentially over the last twenty years. However, as Figure 1 shows, the percentage of the total sum of state subsidies for the NonGov theatres and the number of NonGov theatres subsidised does not always correlate.

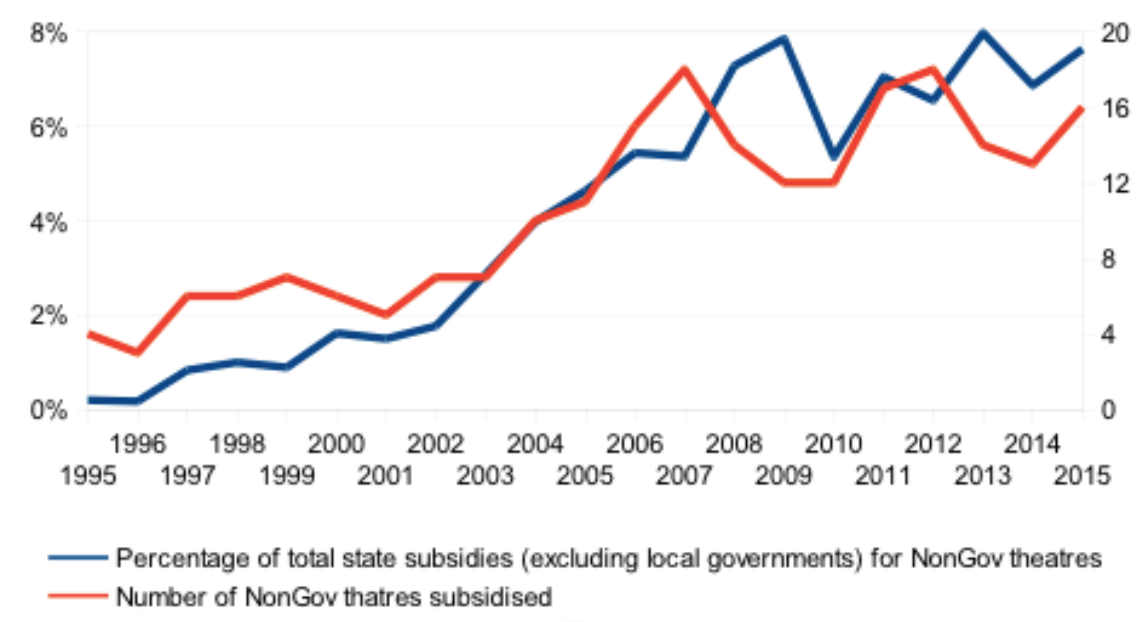

FIGURE 1. Percentage and number of NonGov theatres subsidised by the state in 1995-2015. Source: Estonian Statistics, Estonian Theatre Agency.

15 The general principles of the cultural policy up to 2020 , adopted by the Estonian parliament on 12.02.2014.

16 Girard 1983, 180.

17 More correctly: the foundations are state-established and operate as independent juridical entities by private law. The latter is also the reason why other theatres will be called non-governmental theatres and not private. 
As Figure 1 shows, the number of NonGov theatres subsidised by the state has risen from four to sixteen and the percentage of subsidies for NonGov theatres from 0,2 to 7,63. This follows the development of the performing arts field in Estonia and could be seen as a positive trend, but Figure 1 also demonstrates that since 2004 the number and percentage of subsidies for NonGov theatres does not correlate. Thus in 2007, for example, the number rose but the percentage decreased slightly and, on the other hand, in 2009, the percentage increased but the number decreased. The example of 2007 suggests that there is a limited amount of subsidy for NonGov theatres that does not depend on how many of these theatres are subsidised and that the state does not actually have a clear policy of how many NonGov theatres it should subsidise.

In the following analyses the National Opera and city-theatres will be excluded for a better comparison of state-owned and NonGov theatres. As a result of the first subsidy since the public law was passed, opera actually gets its subsidy directly from Parliament (it receives on average $30 \%$ of all the subsidies for the performing arts field) and does not therefore compete for the same money as other theatres. Two city-theatres, however, do compete for the same money (they receive on average four percent of state subsidies) in addition to getting about $40 \%$ of their subsidies from respective local governments, but they are very different from each other both in size and function: Kuressaare City Theatre receives six to ten thousand visits in a calendar year and operates as a project-based theatre while Tallinn City Theatre has around 70,000 visits and works as a repertoire theatre - as do the rest of the eight state-owned theatres.

These eight theatres, called the G8, ${ }^{18}$ get on average $60 \%$ or more of the state subsidies for theatres, the state-subsidised theatre-visits and the total income from ticket sales in any calendar year. To put it in perspective, the state-subsidised NonGov theatres receive about $15 \%$ of the theatre-visits with their $7 \%$ from state subsidies. This means that for the state, the average cost of one theatre-visit - and accessibility is the core principle of the democratisation of culture that Estonia also follows as shown before - in G8 theatres is higher than that of the NonGov theatres, as is shown in Figure 2.

$18 \quad$ The term G8 for state-owned theatres operating as foundations (Estonian Drama Theatre, Vanemuine, Estonian Russian Theatre, Estonian Puppet Theatre, Theatre N099, Endla Theatre, Rakvere Theatre and Ugala Theatre), inspired by the G8 of the political forum of the world's major highly industrialized economies, was first suggested by me. See: Karulin 2014. 


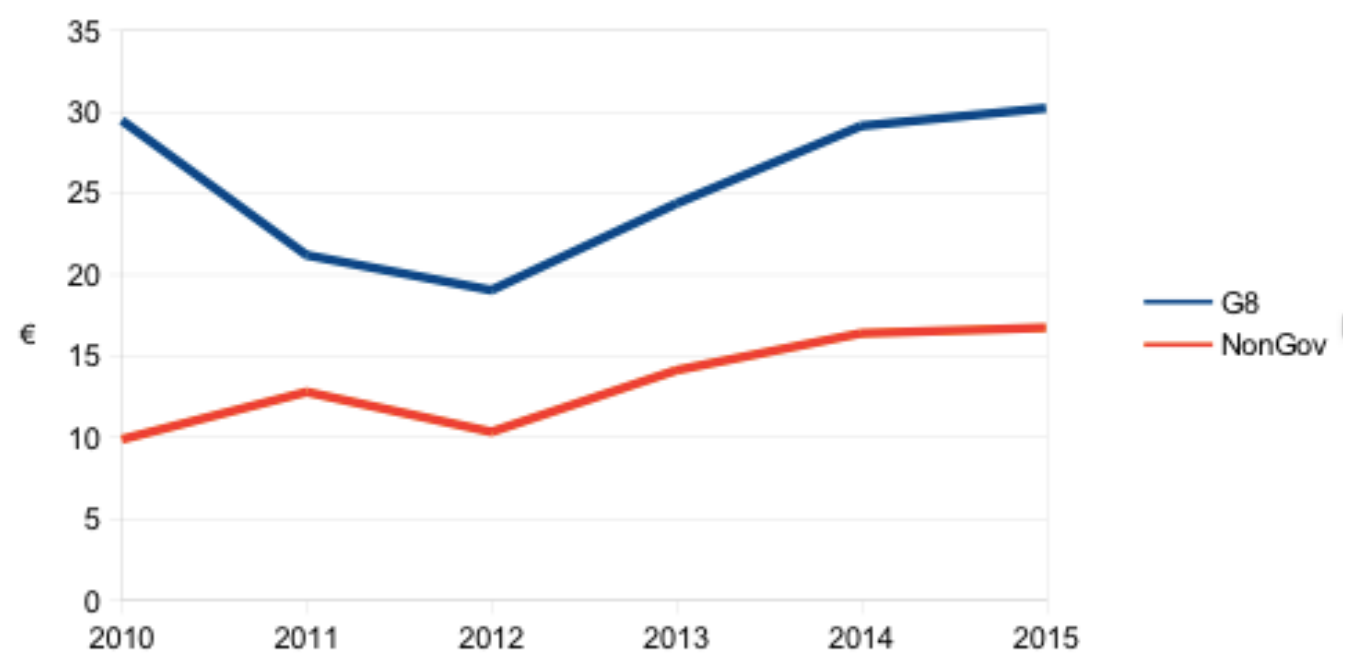

FIGURE 2. The cost of one theatre-visit.

Source: Estonian Theatre Agency.

The difference between the cost of a state-subsidised theatre-visit of G8 and NonGov theatres has, in recent years, almost doubled, as Figure 2 demonstrates, and was, for example, in 2015 thirty vs. seventeen euros. The difference was greatest in 2010, right after the economic crisis when NonGov theatres managed to raise the number of their theatre-visits by $13 \%$, and G8 almost remained the same, only to be the smallest the following year, when NonGov theatres lost $11 \%$ of theatre-visits and G8 gained $8 \%$, suggesting that the economic crisis hit NonGov theatres a year later. Since 2013 the increase of the cost of one theatre-visit correlates between the two groups.

The higher cost of G8 theatre-visits is dependent on the type of subsidies different theatres can hope for, particularly the subsidies for theatre venues. State-owned G8 theatres all have their own venues and the state subsidises both the management of these buildings and the investments made to them. NonGov theatres do not, as a rule, get that kind of subsidy even if they own or have a long-term rental contract with a venue, as is evident from Figure 3, which shows the structure of subsidies for G8 and NonGov theatres. It is also worth bearing in mind the total amount of subsidies from 2010 to 2015 for G8 and NonGov theatres - that is 95,7 and 12,3 million respectively, or in other words, the subsidy for G8 theatres is almost eight times greater than that for the NonGov theatres. The total number of visits for this period is only four times greater in G8 theatres. 


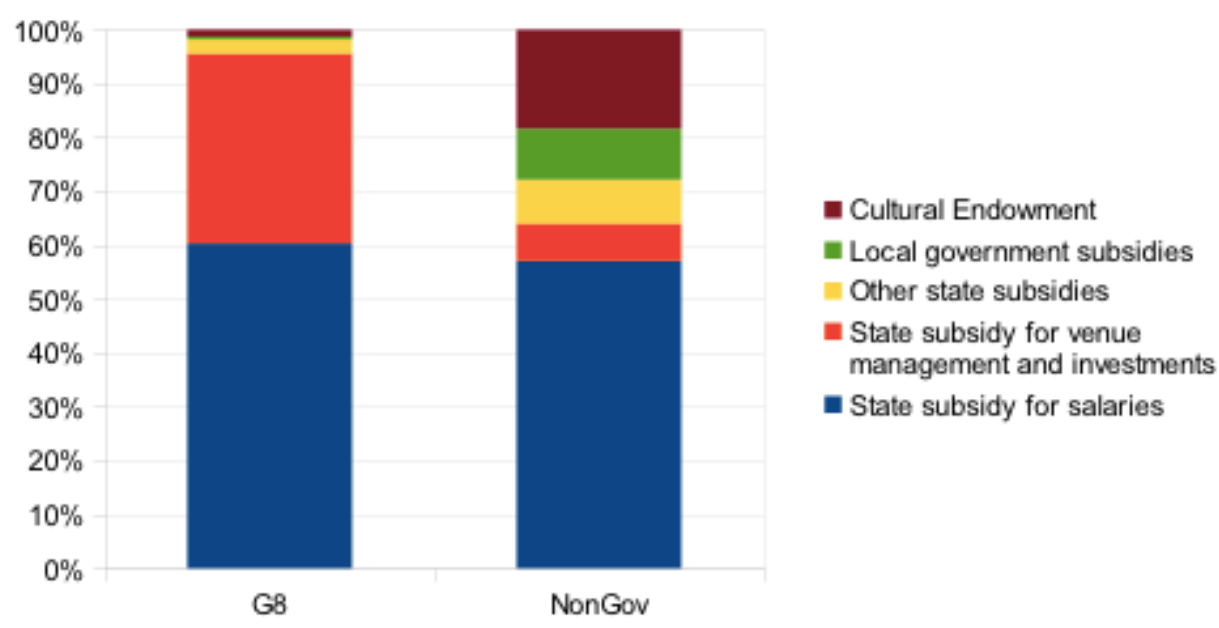

FIGURE 3. The structure of subsidies for G8 and NonGov theatres (the percentages of the total sum of subsidies from 2010 to 2015). Source: Estonian Theatre Agency.

Proportionally, the largest of the subsidies shown in Figure 3 in the context of all the subsidies granted for both G8 and NonGov theatres is the state subsidy for salaries that makes up, respectively, $60 \%$ and $57 \%$ of all subsidies. The biggest gap in subsidies between G8 and NonGov theatres is indeed the state subsidy for venue management and investments that makes 35\% of the subsidies for G8 theatres and 7\% for NonGov theatres. Furthermore, almost half of the state subsidy for venue management and investments for NonGov theatres goes to one theatre called Vaba Lava (Free Stage). The case of Vaba Lava will be analysed in detail in the final section of this article as will the way in which the Culture Endowment of Estonia operates - both of which are the state's attempt at securing cultural democracy. But it is already evident from Figure 3 that the endowment plays only a marginal role for G8 theatres (only one percent of all their subsidies), whereas for NonGov theatres the grants from the endowment are the third biggest type of subsidy, accounting for $18 \%$ of total subsidies. Local government subsidies also have next to no input for G8 theatres (less than one percent) but are important for some NonGov theatres ( $9 \%$ of the total subsidies), meaning that local governments do not usually have a policy of subsidising theatres through open-call applications (although they might have them for smaller amounts) but rather choose to support a theatre or two operating in a building in their jurisdiction (as do Tallinn and Tartu, two of the biggest cities in Estonia).

All this - the lower subsidy per theatre-visit for NonGov theatres and the great gap in the state subsidy for venue management and investments $(33,7$ million for G8 theatres and less than a million for NonGov theatres over the period of 2010 to 2015 ) - is proof of two things: that it is economically sensi- 
ble to be a state-owned theatre and that G8 theatres are natural monopolies possessing the majority of resources (venues as well as subsidies) in the performing arts field, making it economically unreasonable for any other theatre to duplicate these resources. In other words: since the ratio and structure of state subsidies for G8 and NonGov theatres has not changed significantly over the last few years, the latter have no reason to expect more. That also means that NonGov theatres do not have the economic certainty to invest either in their venues or personnel, making growth impossible.

In a market economy, as explained by Ruth Towse, the monopoly firm is one that "can control the market and set the price they wish to, though they are constrained in that by consumers' demand."19 This would be imaginable for example in a market with only one theatre and would be therefore only temporary since there are bound to be competitors. However, this is not the case with a natural monopoly: "Such enterprises are expected to have very high fixed costs but also very low marginal costs." ${ }^{20}$ G8 theatres, with their permanent venues and employees (artistic troupe included), do have very high fixed costs and have to - even despite the state subsidy - produce a certain amount of productions to manage the building and pay salaries. At the same time, their marginal cost, that is a cost of producing another unit (a production), is much lower than for a NonGov theatre with no permanent venue or troupe. Also, the cost for a NonGov theatre to have its own permanent venue and/or a troupe would be too high and "act as a barrier to entry." ${ }^{21}$ Or, as is stated in the Estonian Competition Act, "An undertaking is deemed to be in control of an essential facility or to have a natural monopoly if it owns, possesses or operates a network, infrastructure or any other essential facility which other persons cannot duplicate or for whom it is economically inexpedient to duplicate but without access to which or the existence of which it is impossible to operate in the goods market"22, and the "Dominant position is presumed if an undertaking accounts for at least 40 per cent of the turnover in the market or several undertakings operating in the same market account for at least 40 per cent of the turnover in the market."23 The latter is valid for the performing arts field in Estonia where G8 theatres receive $60 \%$ of both state subsidies and visits, as shown earlier.

Furthermore, this ratio has not changed regardless of the exponential growth in the number of NonGov theatres over the last few years (in 2010 fifteen theatres submitted their production, attendance, and economic statistics for the Estonian Theatre Agency that collects it on behalf of the state, while 38 did so in 2015). This suggests that G8 theatres are not influenced by the NonGov theatres in regards of their state subsidy or the number of

\footnotetext{
19 Towse 2010, 121.

20 Towse 2010, 125.

21 lbid.

22 Competition Act, §15,

23 Competition Act, §13.
} 
visits and the latter have to compete mainly with each other. Furthermore, there are only nine NonGov theatres that have been state-subsidised every year since 2010, of which two are semi-professional, so this article will focus on the seven professional ones (let's call them the Seven Dwarfs). ${ }^{24}$ Figure 4 demonstrates that the Seven Dwarfs get $70 \%$ of all the subsidies for NonGov theatres and are therefore a natural monopoly in the sub-market of non-governmental theatres as are the G8 theatres in the whole of the Estonian theatre market.

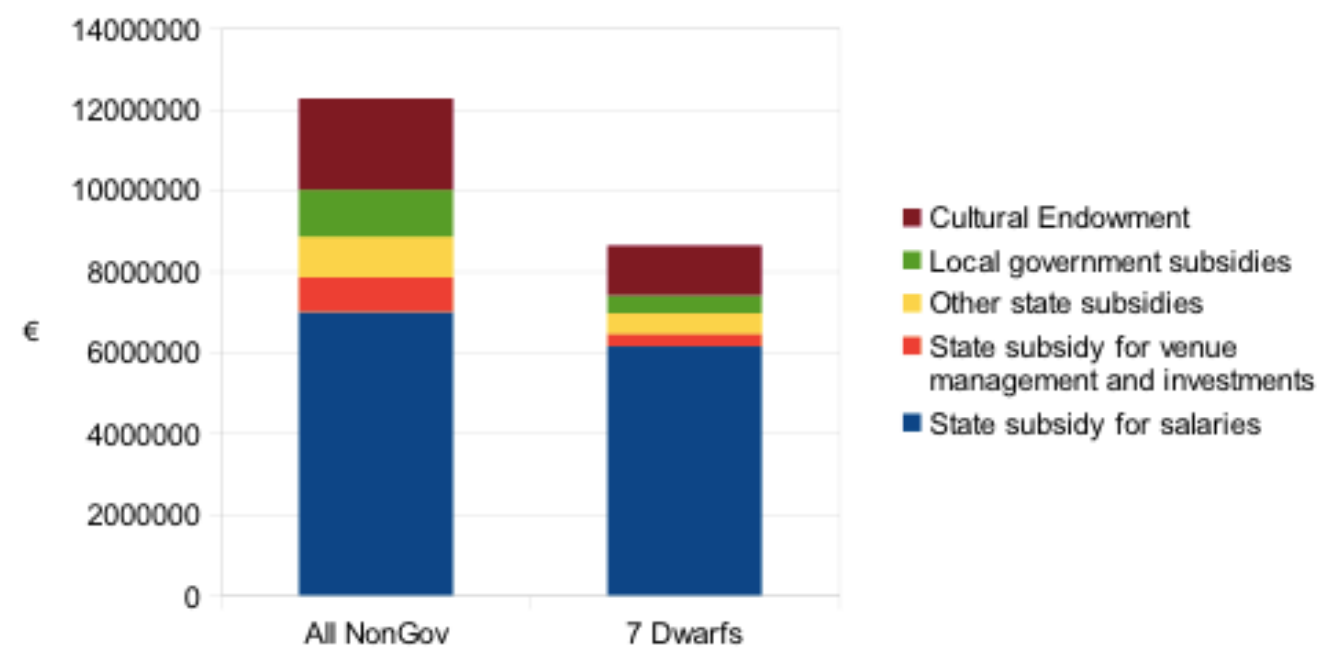

FIGURE 4. The total sum of subsidies from 2010 to 2015 for NonGov theatres (all and the Seven Dwarfs). Source: Estonian Theatre Agency.

The reason why the Seven Dwarfs only get $37 \%$ of the state subsidy for venue management and investments as shown in Figure 4 is that Vaba Lava opened the doors to its building in 2014 and has been subsidised from 2013. They also collect only $38 \%$ of the local government subsidies and $54 \%$ of the grants from the Cultural Endowment of Estonia suggesting that these are the subsidies NonGov theatres without a direct subsidy from the Ministry of Culture are more eager to ask for and/or the Seven Dwarfs, getting $88 \%$ of the state subsidy for salaries, do not (have to) apply for. So it seems that in securing cultural democracy (the equal access to the necessary resources to create), the Cultural Endowment of Estonia plays a significant role. This and the case of Vaba Lava will be analysed next.

$24 \quad$ These seven theatres are: Kanuti Gildi SAAL, R.A.A.A.M, Sõltumatu Tantsu Ühendus, Theatrum, Vana Baskini Teater, VAT Teater, Von Krahli Teater. 


\section{THE CULTURAL ENDOWMENT OF ESTONIA AND VABA LAVA}

As has been referred to before, the aim of the Cultural Endowment of Esto$\mathrm{nia}^{25}$ can be seen as balancing the decisions of the Ministry in the context of cultural democracy as it mainly supports creative individuals, whereas the Ministry focuses on institutions. In Table 1 two years - 2010 and 2015 - of the activities of the endowment for performing arts are compared.

\begin{tabular}{|c|c|c|c|c|}
\hline & $\begin{array}{c}\text { Total sum of } \\
\text { grants }\end{array}$ & $\begin{array}{c}\text { Grants for } \\
\text { productions } \\
\text { (\% of total } \\
\text { sum) }\end{array}$ & $\begin{array}{c}\text { Number of } \\
\text { productions } \\
\text { with grant(s) }\end{array}$ & $\begin{array}{c}\text { Productions of } \\
\text { theatres with } \\
\text { state subsidy } \\
\text { (\% of pro- } \\
\text { ductions with } \\
\text { grants) }\end{array}$ \\
\hline 2010 & $1,260,826$ & $27 \%$ & 132 & $36 \%$ \\
\hline 2015 & $1,628,537$ & $39 \%$ & 146 & $45 \%$ \\
\hline
\end{tabular}

TABLE 1. The grants of the endowment for performing arts in 2010 and 2015. Source: the Cultural Endowment of Estonia.

In the first column of Table 1, the total sum of grants given by the endowment for performing arts in respective years is shown. It should be noted that the total sum of state subsidies for performing arts was 26,2 million in 2010 and 30,6 million in 2015, so the grants of the Cultural Endowment of Estonia only make about four to five percent of total subsidies. Furthermore, the endowment for performing arts is the main subsidiser of the Estonian Theatre Union and international theatre festivals held in Estonia, and also supports guest performances of Estonian theatres abroad and creative individuals attending workshops or visiting foreign festivals, etc. So, the second column shows how many grants are given for producing and performing new productions and the third one how many productions have received grants. The latter number is so high (there are on average 200 new productions in Estonia in a year) because a production could get a subsidy from five hundred euros (for a fee of a sound designer for example) to up to fifteen thousand euros,

25 The Cultural Endowment of Estonia was re-established in 1994 and gets its income from the gambling tax, of which $46 \%$ is allocated to the Endowment (63\% of the allocations of the Endowment must be given to cultural buildings). There are eight specialised endowments (performing arts among them) and an expert group for each county. Each endowment has seven members that are selected by the Minister of Culture from candidates put forward by culture institutions. 
which is the maximum amount for one production. The last column shows the percentage of productions with grants produced in a state-subsidised theatre. Remember that in Figure 4, the ratio of grants from the endowment for the Seven Dwarfs was 54\%, which is lower than shown in Table 1 . The latter is due to the specificity of the grants given: the grants for creation (for a director, choreographer, dramaturg and set, lighting, sound and video designer) are individual and are not / could not be taken into account in the statistics of institutions that Figure 4 is based on. In Table 1, the aforementioned individual grants and institutional grants (for example actors' salaries and subsidy for set decoration) have been combined.

The case of individual grants is of most interest here. As stated before, the G8 theatres are natural monopolies possessing the majority of resources such as subsidies and venues. The third resource they possess is the socalled social guarantees for their employees. In Estonia, the employer pays a social tax of $33 \%$ in addition to the salary agreed with the employee for the benefit of the latter. This social tax is the basis for an employee to get the state-paid health insurance (the possibility to go to the doctor for free but also the right for maternity leave and so on), and the state pension depends on the number of years that one has worked. In the case of individual grants from the endowment, no social tax (or any other tax for that matter) is paid and therefore no contribution to the health or pension system is made. For freelance artists who never get paid as employees (or do sporadically) this is a problem: there is a voluntary health insurance option but one can only apply for it after the social tax has been paid for him or her by some employer(s) in the previous twelve months. Without going into too much detail (the Ministry of Culture is advocating changes to the respective laws), this much is certain, the system today favours those working in G8 theatres as full-time employees.

Since, as was concluded earlier, the cost for a NonGov theatre to have its own permanent venue and/or a troupe would be unreasonably high, there does not seem to be a way out of this social tax loophole at the moment. Fortunately, the other loophole - the lack of sufficient subsidies for the venues for the NonGov theatres and the state-owned venues being used by G8 theatres ${ }^{26}$ - has been addressed by the Ministry of Culture much more efficiently. Foundation Vaba Lava was established by nine NonGov theatres in 2010 to end the shortage of rehearsal rooms and venues for performing. In 2014, they opened a new venue built with the help of a private investor and the promise by the Ministry of Culture to reimburse this investment for the investor over a period of seven years starting from 2013. The concept of such

26 G8 theatres do rent out their venues but usually only on one day in a week when their own troupe has a day off and even then other G8 theatres (having their day off on another weekday) do most of the renting as the venues are too big (Italian style stages with more than four hundred seats) for the productions of NonGov theatres that usually perform in smaller venues (since they have no access for bigger ones in the rehearsal stage of the production). 
a free stage is not new in Estonia (although the financing scheme was) since the contemporary dance field has worked in this way (two central production houses with a venue that curate their program from the work of freelancers) for more than ten years. The difference of Vaba Lava is the state's willingness to subsidise the management of its building - the two dance-houses have never received such subsidies from the Ministry of Culture, although one of them is supported by the municipality of Tallinn and the other is now renting a venue from foundation Vaba Lava.

The latter is just finishing its third season, so long term conclusions have to wait. In 2015, they gave 126 performances that achieved 15,626 visits, which makes them the sixth most-visited NonGov theatre in that year. However, the initial aim of having a free stage easily accessible for many NonGov theatres has not yet come to life as Vaba Lava has focused on its own curatorial program and other theatres have been heard complaining that to rent this venue is above their means. The Ministry of Culture should probably evaluate the situation of Vaba Lava in the near future since it was meant to attain the cultural democracy that the subsidies of the Ministry do not do. Furthermore, the unequal approach from the Ministry of Culture towards dance-houses and Vaba Lava regarding the subsidy for the management of their venues is questioned by NonGov theatres more and more and will not subside before the state proposes an action plan on how to deal with the dilemma between the democratisation of culture and cultural democracy.

\section{CONCLUSIONS}

This article addressed three questions: to what extent has the state set securing cultural democracy (vs. the democratisation of culture) in performing arts in Estonia as its policy goal; what role do G8 theatres as natural monopolies play in this context, and what has the Estonian state done to compensate other theatres for the aggregation of resources to G8 theatres? Analyses of the subsidies allocated by the state to the performing arts institutions showed that the Estonian state follows mainly the principles of the democratisation of culture, focusing on the access to consumption rather than production - regardless of the activity of the Cultural Endowment of Estonia which does not have enough resources to secure cultural democracy. This analysis also verified that the G8 theatres are indeed natural monopolies monopolizing resources such as subsidy, venue, and social guarantees for individuals that the NonGov theatres cannot challenge nor replicate. Furthermore, the sub-market of NonGov theatres has its own natural monopolies, just like the G8 theatres in the whole Estonian theatre market, that monopolize one of the main resources - that is the subsidy from the Ministry of Culture (and not, perhaps surprisingly, the subsidies from the Cultural Endowment of Estonia). Finally, two cases of the state's attempt to secure cultural democracy - that of the Cultural Endowment of Estonia and Vaba Lava - were presented.

Further research would be fruitful in analysing the influence of natural monopolies in the field of the performing arts on not only the economic but also 
artistic choices of other theatres. For example: do NonGov theatres perform in smaller venues because it is their artistic choice, or because they do not have access to bigger venues? If this is an outcome of restriction, what could a state do to change this situation and would, for example, the sharing of venues of G8 theatres orchestrated and ordered by the Ministry of Culture have undesirable results (such as an increased number of freelance artists and the question of their social guarantees or the influence on the artistic identity of NonGov theatres by producing their work in bigger venues and on securing cultural democracy)?

\section{REFERENCES}

Aadamsoo, Martin, Evi Arujärv, Indrek Ibrus, Andres Jõesaar, Ott Karulin, Egge Kulbok-Lattik, Ülar Mark, Ruth-Helene Melioranski, Pille Runnel, Ingrid Rüütel, Külliki Tafel-Viia, Margaret Tali and Märt Väljataga 2012. Eesti kultuuripoliitika põhimõisted ja suundumused. Tallinn: Eesti Kultuuri Koda, kultuuripoliitika uuringute töörühm.

Competition Act.

https://www.riigiteataja.ee/en/eli/ee/Riigikogu/act/501062017001/consolide

The general principles of the cultural policy up to 2020

http://www.kul.ee/sites/kulminn/files/culture2020 eng.pdf

Girard, Augustin (in collaboration with Geneviève Gentil) 1983. Cultural development: experiences and policies. The United Nations Educational, Scientific and Cultural Organization (UNESCO) France. (first published in 1972)

Karulin, Ott. 2014. "Eesti teatri G8." Sirp, 18 Sept 2014.

Matarasso, François \& Charles Landry. 1999. Balancing act: twenty-one strategic dilemmas in cultural policy, Cultural Policies Research and Development Unit, Policy Note No. 4, Council of Europe Publishing, Belgium.

Towse, Ruth. 2010. A Textbook of Cultural Economics. New York: Cambridge University Press.

\section{AUTHOR}

Ott Karulin has a PhD in theatre studies from the University of Tartu (2013). In his dissertation, he focused on the functioning of state-funded repertory theatres in Estonia from 1985 onward. He is also an active theatre critic and is currently the editor-in-chief of an Estonian weekly newspaper, Sirp, which deals with cultural issues. 